\title{
Gender Based Violence: Justice and Reparation in Bosnia And Herzegovina
}

\section{Colette Donadio}

\author{
Albert Ludwigs Universität Freiburg
}

E-mail: colettedonadio@yahoo.it

\author{
Doi:10.5901/mjss.2014.v5n16p692
}

\begin{abstract}
This article examines the process of Reparation and Justice for the rape victims in Bosnia and Herzegovina in the period stretching from 1995 to 2014. The aim of the author is to demonstrate that, in the aftermath of the Yugoslavian war, this process has in fact only partially being enacted. On the basis of the reports produced by the NGOs carrying out fieldwork in $\mathrm{BiH}$, and in spite of international outrage and widespread media attention, very little has been done to ensure the survivors' rights to justice, truth and reparation. Many of the victims are still struggling to rebuild their lives. This article compares how the process of reparation should idealistically be implemented and what is actually taking place in BiH by explaining what should be entailed in the processes of rehabilitation, compensation and restitution of property and the manner in which the ICTY and the local governments are involved.
\end{abstract}

Keywords: Bosnia Herzegovina; Yugoslavian War; Icty; Rapes; Reparation; Justice; Compensation; Restitution; Gender Based Violence.

\section{Introduction}

It is necessary, first of all, to outline the context in which sexual violence occurred in the country formerly known as Yugoslavia and to provide a definition of Gender Based Violence. Gender Based Violence against women has been defined, from a broad point of view, as "Any act that results in, or is likely to result in physical, sexual, or psychological harm or suffering to women, including threats of such acts, coercion or arbitrary deprivation of liberty, whether occurring in public or private life"1

This is the definition that was given at the United Nations Conference on Women in Beijing in 1995, where the patterns and characteristics of GBV were summarized in order to proceed legally with codified standards.

The civil and ethnic war in Yugoslavia broke up the original unity of the country and caused the nation to split into many different states.

An investigative commission sent by the U.N. Security Council concluded that the rape of Muslim women had occurred on "a wide scale" and as "part of a clearly recognizable pattern."2. The conflict spread across different areas and moments: Bosnia and Herzegovina (1992-1995), Croatia (1991-1995), Slovenia (1991), Kosovo (1998-1999), Macedonia (2001).

The main reports concerning rapes were in Bosnia and Herzegovina and Kosovo, but numbers have never been available nor precisely calculated. According to the Final Report of the Commission of Experts Established Pursuant to Security Council Resolution $780^{3}$, the victims ranged from 20.000 to 50.000 . They were women and they were raped 4 . More specifically, the rapes were carried out on Muslim women and the perpetrators were Serbian soldiers. The way the rapes were perpetrated varied, both in 'method' and place: women were subject to violence at home or in public. The violence was carried out in the presence of the victims' families and by means of a variety of objects, such as glass, guns or any other object at hand ${ }^{5}$. One of the most horrendous ways the rapes were perpetrated was in the so called "rape

\footnotetext{
${ }^{1}$ United Nations, 1995, Platform for Action D. 112

${ }_{2}^{2}$ International Court of Justice, General List No. 91; Application; Instituting Proceedings filed in the Registry of the Court on 20th March 1993; Application of the Convention on the Prevention and Punishment of the Crime of Genocide (Bosnia and Herzegovina v. Yugoslavia (Serbia and Montenegro). Application of the Republic of Bosnia and Herzegovina. 20th March 1993.

${ }^{3}$ Final Report of the Commission of Experts Established Pursuant to Security Council Resolution 780 (1992), S/1994/674, 27 May 1994, Chapter IV, F.

${ }^{4}$ Of course men were also raped, but they did not represent the majority of the cases. In order to narrow the focus of this work, I excluded these cases from the investigation.

${ }^{5}$ Refer to note $n^{\circ} 1$.
} 
camps". These places were specifically organized sites where women were kept captive and forced to have sex in order to be impregnated; they were forced in the camps until it was too late to end the pregnancy and choose to have an abortion. These camps were set up on the basis of a patrilineal structure of society: the logic being that if, as clearly happened, the child were sired by a Serb father it would inherit his ethnicity. More than $35000^{6}$ women and children were held in captivity. A Human Rights Watch, report published in 2000 states: "... Rapes in women's homes, rapes during flight, and rapes in detention. In the first category, security forces entered private homes and raped women either in the yard, in front of family members, or in adjoining room. In the second category, internally displaced people wandering on foot and riding on tractors were repeatedly stopped, robbed, and threatened by the Yugoslav Army, Serbian police, or paramilitaries. If families could not produce cash, security forces told them that their daughters would be taken away and raped; in some cases, even when families did provide money, their daughters would be taken away. The third category of rapes took place in temporary detention centers, such as abandoned homes or barnes"'. Throughout the war many of the rapes were committed, as previously mentioned, by Serbian paramilitaries, special police task forces or Yugoslavian soldiers from the army, and usually the rapes were carried out by at least two men. The rapes took place with the quiescence of both the Serbian and Yugoslav Governments. And even though the authorities and institutions were well aware of what was happening, nothing was done to prevent such crimes from happening over and over again. This is the general, broad picture that I initially provide in order to begin a more detailed investigation.

\section{Prosecuting Sexual Violence: the ICTY's work in Bosnia and Herzegovina}

Prior to the establishment of tribunals such as the ICTY, the ICTR and the ICC, the juridical evolution of criminal courts took place in four distinct phases: the first phase goes from archaic history to World War II, 1945; the second phase from World War II to the two Tribunals of Nuremberg and Tokyo, in the 1940s and the third phase includes the birth of the ICTY and ICTR, which were in the Nineties. The fourth and last phase is marked by the creation of the ICC in 1998.

This article focuses mainly on the third phase. The following paragraph will outline the constitution and functioning of the ICTY.

The ICTY is located in The Hague, Netherlands. It was created in 1993 and it is very similar in structure, and in the crimes it deals with, to the Criminal Tribunal of Rwanda, which was established in 1994 in Arusha, Tanzania.

The ICTY comprises three organs: the Chambers, the Office of the Prosecutor and the Registry.

The jurisdiction of the Tribunal is linked to the need to judge crimes which were committed in specific regions: the former Republic of Yugoslavia which is now Croatia, Macedonia, Bosnia and Herzegovina, Kosovo. The time span that is "covered" by the legislative power of the Tribunal dates back to 1991, it therefore relates to all the crimes committed from that date. The conflicts that cannot be judged pertain to the area located on the border of Slovenia.

The creation of the ICTY was handled by the United Nations Security Council with Security Council Resolution 808 and Security Council Resolution 827. The Resolution approach (adopted in spite of the Treaty approach) was more appropriate for the conflict situation and it was chosen because it had an immediate binding and enforcing effect on the States where war had taken -or was taking- place. The decision to approve the creation of the Tribunal was taken after the Commission of Experts had thoroughly examined the consequences of war on the Yugoslavian territory with Resolution 780. This Resolution confirmed that grave humanitarian breaches had occurred: killing, ethnic cleansing, mass rapes, torture and other atrocious crimes. Resolution 820 , in 1993, stated that 'all violations on international humanitarian law, including in particular the practice of 'ethnic cleansing' and the massive, organized and systematic detention and rape of women' were to be condemned. Finally in 1994, the ultimate Report 780 was the definitive step towards the creation of the Tribunal; most importantly, for the first time rape was recognized as an act that was an integral part of conflict and was legally standardized in Article 5(g).

The Statute of the ICTY bans rape outright, this is clearly a huge step forward when compared to the Nuremberg or Tokyo Statutes. The crimes that have been prosecuted under the ICTY are, in this sense, gender-specific.

As stated in Security Council Resolution 1503, a number of specific rulings and articles which contribute to the structure and procedures of the tribunal are of great significance, as is detailed below:

Rule 96 - "Provides that corroboration of the testimony of a victim of sexual violence is not required. This rule ensured that the crime of sexual violence would not fall under the stringent evidentiary standards applied to other types of crimes, thus addressing a problem experienced in some domestic systems. It shows a realistic understanding of the

\footnotetext{
${ }^{6}$ According to the Women's Group Tresnjevka

${ }^{7}$ Human Rights Watch (2000), quoted from Anne-Marie L.M. De Brouwer Supranational Criminal Prosecution of Sexual Violence, ( Intersentia, 2005)
} 
particular nature of the crime of sexual violence, which often takes place with no witnesses or only witnesses acting in collaboration with the perpetrator..$^{\prime \prime}$

Article 22 of the Statute of the ICTY - "The International Tribunal shall provide in its rules of procedure and evidence for the protection of victims and witnesses. Such protection measures shall include, but shall not be limited to, the conduct of in camera proceedings and the protection of the victim's identity."

And Rule 34 - "There shall be set up under the authority of the Registrar a Victims and Witnesses Section consisting of qualified staff to: (i) recommend protective measures for victims and witnesses in accordance with Article 22 of the Statute; and (ii) provide counselling and support for them, in particular in cases of rape and sexual assault. "10

This brings us to the next step, the analysis of the effective consequences of the processes of reparation to victims of sexual violence in Bosnia and Herzegovina, with specific regard to restitution of property, compensation and rehabilitation.

\subsection{The process of reparation to victims of sexual violence}

The term 'reparation' encompasses three different concepts: restitution, compensation and rehabilitation ${ }^{11}$. The standardization of these terms relies on the definition initially provided by the Van Boven/ Bassiouni Principles, on which the reparation systems of the ICC, and that of both the ICTY and ICTR are based. Along with the Declaration of Basic Principles of Justice for Victims of Crime and Abuse of Power (1985) ${ }^{12}$ the Basic Principles and Guidelines on the Rights to a Remedy and Reparation for Victims of Violation of International Human Rights and Humanitarian Law (2000) $)^{13}$ - or, as mentioned previously, the Van Boven/ Bassiouni Principles- are the underlying legislative rulings upon which international reparation laws rest.

The Basic Principles and Guidelines on the Right to a Remedy and Reparation for Victims of Gross Violations of International Human Rights Law and Serious Violations of International Humanitarian Law (2005), which were recognised by the Human Rights Commission, state that:

"19. Restitution should, whenever possible, restore the victim to the original situation before the gross violations of international human rights or serious violations of international humanitarian law occurred. Restitution includes, as appropriate: restoration of liberty, enjoyment of human rights, identity, family life and citizenship, return to one's place of residence, restoration of employment and return of property.

20. Compensation should be provided for any economically assessable damage, as appropriate and proportional to the gravity of the violation and the circumstances of each case, resulting from gross violations of international human rights law and serious violations of international humanitarian law, such as:

(a) Physical or mental harm;

(b) Lost opportunities, including employment, education and social benefits;

(c) Material damages and loss of earnings, including loss of earning potential;

(d) Moral damage;

(e) Costs required for legal or expert assistance, medicine and medical services, and psychological and social services.

21. Rehabilitation should include medical and psychological care as well as legal and social services"

Reparation generally takes place on two distinct levels: a national and an international one.

On the first level the process takes place through civil -or criminal- lawsuits, whereas on the second level, and this will be the subject matter of the following paragraphs, the process takes place through supranational commissions and/ or courts and mass trials.

The initial approach towards retributive justice has progressively evolved from merely sanctioning the criminal to also taking into consideration the right for reparation, and the participation in trials, of the victims. The ICC created a Trust

\footnotetext{
${ }^{8}$ Data retrieved from the ICTY official website: $h$ ttp://www.icty.org/sid/10313

${ }^{9}$ Data retrieved from the ICTY official website: $h$ ttp://www.icty.org/x/file/Legal\%20Library/Statute/statute_sept09_en.pdf

${ }^{10}$ Data retrieved from the ICTY official website: $h$ ttp://www.icty.org/X/file/Legal\%20Library/Rules_procedure_evidence/IT032_Rev43_en.pdf

${ }^{11}$ As stated in Article 75(1) of the ICC Statute.

12 An annex to the UNGA Resolution 40/34 of the $29^{\text {th }}$ November 1985.

${ }^{13}$ The 'Basic Principles and Guidelines on the Rights to a Remedy and Reparation for Victims of Violations of International Human Rights and Humanitarian Law' are also known as the 'Van Boven/ Bassiouni Principles as they are an annex to the Final Report of Special Rapporteur Cherif Bassiouni. These principles were the natural evolution of previous rulings such as the 'Draft Principles on the Right to Restitution, Compensation and Rehabilitation for Victims of Gross Violations of Human Rights and Fundamental Freedoms', which was in turn an annex to a Report signed by Theo van Boven in 1993.
} 
Fund in order to grant justice to wartime victims of violence (specifically, sexualized violence). This organ was set up for the benefit of the injured parties and their families. The Trust Fund should, at least from a theoretical point of view, consider the victims' needs even before the Trials take place, thus without the concession of the Court to proceed or without its judgement on the case.

The services offered by the Trust Fund are usually not sufficient to satisfy the need for reparation of the victims; but we will address this point later.

The reparation for victims of sexual violence is indeed a special need and should not require any kind of justification. Besides the psychological consequences and the stigmatisation, the raped women contract diseases such as HIV and they have to bear unwanted pregnancies. They also suffer from internal injuries and mutilations. The most compelling problem is doubtless HIV as it is most likely to spread among the female population, especially when sexual intercourse is coerced ${ }^{14}$.

The Tribunals (both the ICTY and the ICTR) theoretically offer a number of opportunities for reparation, in the following paragraphs we will consider how such opportunities should work from an ideal point of view, however, as shall be illustrated, reality often differs from the expected outcomes.

\subsection{Restitution of property}

Based on the principle of unjust enrichment ${ }^{15}$, the possibility of restitution of property is envisioned by the ICTY Statute in Article 24(3) and it is enforced by Rule 105 and Rule 98 of the Rules of Procedure and Evidence. It is important to note that Rule $105^{16}$ in particular, is based on three specific criteria:

- There must be a "guilty party" accused of having taken property by illegal means

- The good or property is related to the accusation

- The Prosecutor or the Chamber should ask for restitution

It is evident that the victim himself/herself cannot claim restitution as s/he is only considered a 'witness', in this case, by the ICTY.

Once these three criteria are met, an audition is set and the good or property is usually returned to the rightful possessor after a pre-trial investigation carried out by the OTP.

If the rightful owner cannot be identified then the national jurisdiction steps in and the Trial follows a more uneven course, as the national and regional institutions are not always available to take part in these investigations. This is why the victims sometimes struggle with bureaucracy and end up not having their needs met.

\subsection{Compensation}

The process of compensation is not part of the Tribunal's remit and is usually dealt with at a national level. All issues and procedures relating to compensation are the responsibility of national authorities and institutions as stated in Common Rule $106^{17}$.

14 WHO, Women and Girls need Access to AIDS Treatment and Protection from Violence, 2004

15 The criminal should not benefit from anything that was the victim's property

${ }^{16}$ Rule 105 claims: (A) After a judgement of conviction containing a specific finding as provided in Rule 98 the Trial Chamber shall, at the request of the Prosecutor, or may, proprio motu, hold a special hearing to determine the matter of the restitution of the property or the proceeds thereof, and may in the meantime order such provisional measures for the preservation and protection of the property proceeds as it considers appropriate. (B) The determination may extend to such property or its proceeds, even in the hands of third parties not otherwise connected with the crime of which the convicted person has been found guilty. (C) Such third parties shall be summoned before the Trial Chamber and be given an opportunity to justify their claim to the property or its proceeds. (D) Should the Trial Chamber not be able to determine the rightful owner on the balance of probabilities, it shall order the restitution either of the property or the proceeds or make such other order as it may deem appropriate. (E) Should the Trial Chamber not be able to determine ownership, it shall notify the competent national authorities and request them so to determine. (F) Upon notice from the national authorities that an affirmative determination has been made, the Trial Chamber shall order the restitution either of the property or the proceeds or make such other order as it may deem appropriate. (G) The registrar shall transmit to the competent national authorities any summonses, orders and requests issued by a Trial Chamber pursuant to paragraphs (C), (D), (E) and (F).

${ }_{17}$ Rule 106, ICTY: "(A) The Registrar shall transmit to the competent authorities of the State concerned the judgment finding the accused guilty of a crime which has caused injury to a victim. (B) Pursuant to the relevant national legislation, a victim or persons claiming through the victim may bring an action in a national court or other competent body to obtain compensation, (C) For the purposes of a claim made under paragraph $(B)$ the judgment of the Tribunal shall be final and binding as to the criminal responsibility of the convicted person for such injury." 
The request for compensation can be put forward by the injured party of a crime for which the incriminated party has already been convicted. These mechanisms remain on a national level because on an international one the number of settlements would be too high for the Tribunal to bear; and compensation would be too costly. It is for this reason that a claims commission was established. The ICTY mechanism which prioritized restitution over compensation wasn't a concept upon which all the judges actually agreed: many insisted that leaving the matter to the national authorities wasn't going to bring about any positive outcomes (De Brouwer, 2005, p. 399).

One solution was proposed by Carla del Ponte ${ }^{18}$ who recommended the use of frozen assets from the indicted, but this idea was never carried out.

Compensation was in fact never, at this stage, obtained by victims.

\subsection{Rehabilitation}

The reparation and compensation mechanisms have so far had no decisive outcomes.

With regards to rehabilitation, The ICTY did not achieve any significant results, even though the spontaneous monetary donations were invested in various projects and in 2003 and 2004 a number of conferences were organised on the issue of psychological assistance to support those victims who had decided to testify.

Clearly, the Tribunal is not legally obliged nor entitled to act, on the basis of any binding law, in order to provide for the rehabilitation of the victims.

Most of the rehabilitation work has been carried out by NGOs with considerable expertise in the field.

The ICTY Trust Fund is partially covering this process and the ensuing expenses. It relies on spontaneous monetary donations from the Member States and UN institutions.

These donations, which are kept separate from the other expenses of the ICTY, are often insufficient to allow for the scheduling of projects. Consequently, such projects rarely reach a definitive conclusion. Doubtless, the ICTY should contemplate the idea of setting up a Special Fund for Victims following the ICTR model which was established on the basis of Rule $34^{19}$ from the Rules and Procedures. Rule 34 outlines the kind of support required by victims and the fact that they rely on NGO projects and cooperation for such assistance.

\section{The Central Question: the Reparation Mechanisms}

The central question, and the focus of this article is to illustrate what is really going on in $\mathrm{BiH}$, and to examine whether the victims of wartime violence have truly been indemnified for the suffering they have been subjected to.

This point will be addressed in the following paragraphs.

As has previously been mentioned, a considerable part of the reparation work has been carried out by NGOs, especially in the rehabilitative stage of the reparation process.

These NGOs offer psychological assistance and provide housing, counselling and sheltering for the victims of sexual violence.

Analysis has been carried out on reports from internationally relevant NGOs, locally based NGOs and smaller NGOs advocating women's rights, all of which have addressed the matter and claim that the victims of sexualized violence are still awaiting justice: TRIAL, Amica e.V., Amnesty International, Žene Ženama, Medica Zenica, Stop Rape Now, Impunity Watch, Human Rights Watch, Kvinna Till Kvinna, FIDH- Mouvement Mondial des Droit de l'Homme and many more.

In the following paragraphs I will attempt to identify the mismatch between the ideal processes of compensation, restitution and rehabilitation and the real conditions of women living in Bosnia and Herzegovina in the aftermath of the atrocities, with specific reference to what is stated in the NGO reports.

\subsection{Failure of the process of Reparation}

A report submitted in February 2014 by Trial (Track Impunity Always) together with the Women's International League for

${ }^{18}$ Chief Prosecutor in 2000 of the ICTY and ICTR

${ }^{19}$ Rule 34 states: (A) There shall be set up under the authority of the Registrar a Victims and Witnesses Support Unit consisting of qualified staff to: (i) Ensure that they receive relevant support, including and psychological rehabilitation, especially counselling in cases of rape and sexual assault. (B) A gender sensitive approach to victims and witnesses protective and support measures should be adopted. 
Peace and Freedom, the Association of Genocide Victims and Witnesses and the association Movement of Mothers of Srebrenica and Žepa Enclaves, states that "It results therefore that the Court has the option to award part of a claim to the injured parties or to refer them to civil actions. To the knowledge of the organisations submitting the present general allegation, there has not been a single case where compensation has been awarded, and this proves true not only before the State Court of BiH, but also before tribunals at the Entity-level. The explanation usually provided by prosecutors and judges is that it would take too much additional time to prove and decide upon such claims. Injured parties have instead been instructed that they may take civil action to pursue their entire claims under property law." (Trial - Track Impunity Always, 2014).

This is just one of the many proven facts provided by NGOs regarding the failure of Reparation in $\mathrm{BiH}$ : not a single case where compensation has been awarded. This report is just one of many which claim that the government of Bosnia and Herzegovina has not been providing justice for all the women raped during the war. The perpetrators are still evading justice, righteous punishment and judgement.

It must be highlighted that according to the reports provided by Trial, (Trial, Association of Women-Victims of War, Women's Section of the Concentration Camp Torture Survivors Canton Sarajevo, Foundation of Local Democracy, IzvorPrijedor, Medica Zenica, Naš Glas, Snaga Žene, Society for Threatened Peoples, Sumejja Gerc, Vive Žene Tuzla, 2013) up until March 2013 the Court of Bosnia and Herzegovina had prosecuted forty two cases of Gender Based Violence.

Of these forty two cases, five have reached the first instance and two the second 20 .

The official figures provided by Trial concerning wartime victims of rape range from 20,000 to 50,000 women, it is therefore blatantly evident that there is an unconfutable prevalence of un-punished prosecutors and that impunity is rife. This is also true for the fulfilment of the National Strategy for War Crimes: victims die before their rights to reparation are recognized.

In a 2012 report, The European Commission released a note which stated that "Efforts to investigate and prosecute these crimes and to protect victims and witnesses need to be stepped up. [...] Overall, there has been limited progress in the area of judicial system reform. A constructive attitude towards the need for a comprehensive reform of the judiciary emerged in the Structured Dialogue on Justice, based on domestic ownership, including the implementation of the Justice Sector Reform Strategy and the National War Crimes Strategy. Further measures were introduced to reduce the backlog of cases, particularly of utility bill cases, but the overall backlog remains very high. Lack of investigative capacities and appropriate resources makes the reduction of the backlog of war crime cases highly unlikely. The need to harmonise the application of criminal laws throughout the country and the fragmentation of organisations and budgets constitute serious drawbacks. A number of issues need to be addressed." (EU Progress Report 2013; quoted in Trial Track Impunity Always, 2013).

The evidence of the lack of prosecution and reparation is striking and both international institutions and NGOs report failures in the process.

Many claim that the laws are antiquated (Amnesty, 2010) and that the survivors are not granted support, shelter and assistance, and find themselves facing stigmatising situations.

Reports from FIDH, Amnesty and Impunity Watch describe traumatized victims who refuse to go back to their households as they are denied access to health services and rejected by their local communities.

In depth analysis of the data presented in these reports repeatedly highlights the failure of compensation, restitution of property and rehabilitation.

\subsection{Failure of compensation}

According to Amnesty International ('Whose justice? The Women of Bosnia and Herzegovina are Still Waiting', Amnesty, 2009), the failure of compensation is to be attributed to the $\mathrm{BiH}$ authorities, to the lack of implementation of laws, and to the discrimination against women who have been subjected to violence. The deficiencies in the compensation mechanisms are to be attributed to the lack of legal assistance and inclusion mechanisms.

As for the workings at an international level, the International Court of Justice simply never took up the compensation issue.

The measures initiated by the authorities in Bosnia and Herzegovina mainly concern the provisions for the Status of Civilian Victims of war.

Again, according to the NGOs working on GBV in Bosnia and Herzegovina, the main gaps are to be found in the implementation of these laws.

${ }^{20}$ Official data released by the Outreach Office, 2013 
In Republika Srpska, the Law on the Protection of Civilian Victims of War states in Article 1 that those entitled to the Status of Civilian Victims of War are:

"1. citizens of the Republika Srpska who have suffered body damage after 9 January 1992;

2. persons who have, as citizens of the former SFRY, suffered body damage in the period from 18 August 1990 to 9 January 1992, provided they obtain the citizenship of the Republika Srpska and have registered permanent residence in the territory of the Republika Srpska."21

The Law is also valid for relatives of the damaged persons. The problem is that in the Law no distinction is established between "general victims" and victims of rape.

In Euro currency, the amount of money that victims are entitled to ranges from 50 euros to 175.50 euros, depending on the harm inflicted (the level of harm is evaluated by a health commission).

In the Federation of Bosnia and Herzegovina, however, rulings are based on the Law on the Basis of the Social Protection, Protection of Civilian Victims of War and Families with Children.

This law distinguishes between 'civilian' victims and other damaged persons entitled to the status of victim, the benefits are strictly bound to this distinction. Judgement is based on the degree of damage: if the percentage is equivalent to, or higher than 60 per cent, then the person can be granted victim status.

The victims of rape are, however, slotted into another category and this percentage is not being applied to them (Amnesty, 2009). In the Federation of Bosnia and Herzegovina the benefits correspond to 281,50 euros.

\subsection{Failure of restitution}

The restitution issue is strictly connected to the question of Internally Displaced People (IDPs), and discrimination against IDPs is a weighty question.

The reasoning behind this connection stems from the fact that during the war many refugees fled the country and their properties were destroyed or illegally occupied. The European Union's 2008 Progress Report on Bosnia and Herzegovina stated that "Returnees still face discrimination in employment, access to health care, education, pensions and social rights - especially when returning to areas where they are in a minority position. This remains the biggest obstacle to a sustainable return." (Amnesty, 2009).

The point made by a considerable number of NGOs is that not enough adequate restitutions measures were provided and when they were actually provided, they did not meet the needs of the victims. Furthermore, as many IDPs had lost their previous jobs, restitution should also have included the restitution of employment, but this step was not taken. And, of course, a number of IDPs were also victims of rape.

The Law regulating the restitution of property goes by the name of Property Law Implementation Plan. In the Federation of Bosnia and Herzegovina and in Republika Srpska, the IDPs can be granted a return home as long as it is 'safe and dignified'.

However, the meaning of 'safe and dignified' has not been clarified in this law nor in any other.

Indeed, although the 'safe and dignified' conditions had not been met, women who had suffered wartime rape decided to return home; being destitute, they could not do otherwise. When the appropriate conditions for the return are not met, women end up living in communities where they can still run into their perpetrators, their rapists or the criminals who have in some way harmed them.

This condition is remarkably illustrated in this extract from an interview carried out by Amnesty International with a victim of sexual violence: "When I go by car through the village where I used to live I can see all of them. This one is Chetnik, that one is Chetnik, and the other one as well. All of them are my former neighbours. None of them got arrested. I gave my testimonies many times. I know all of them - their names and surnames. I survived three shootings. I was taken away from home by my neighbour Goran! Community? What kind of community is that? It does not exist anymore." (Amnesty, 2009).

The concept of property restitution should evolve and not merely consist in allowing the victims to return to their pre-war domicile. The 'safe and dignified' definition needs to be clarified, and a return strategy needs to be developed that contemplates the fact that victims may face inadequate conditions when returning home, including encountering their perpetrators on a regular basis.

${ }^{21}$ The Guidebook for Victims of War with the relative articles can be found at: http://www.ic-mp.org/wp-content/uploads/2008/02 Iguidebook-wictim-of-war-rs.pdf 


\subsection{Failure of rehabilitation}

The rehabilitation of rape victims is probably one of the most compelling issues to have been neglected by the Bosnian and Herzegovinian authorities.

Article 21 of the UN Basic Principles outlines the services which should be provided for wartime victims of sexual violence: "medical and psychological care as well as legal and social services" (Amnesty, 2009).

This issue is of course strictly related to the capacity of the country to provide the adequate funds to cover rehabilitation costs. In Bosnia and Herzegovina, these costs are not on the same level as in so-called other 'developed' countries of the European Union. Notwithstanding this, no funds whatsoever are being granted to the wartime victims of sexual violence in $\mathrm{BiH}$.

The following extract from the Impunity Watch Report on "War Victims And Gender-Sensitive Truth, Justice, Reparations And Non-Recurrence In Bosnia And Herzegovina" is highly significant: "Victims of war crimes suffer physical, psychological and social consequences. There are severe, permanent and serious effects both on their economic and social circumstances, as well as on a psychological level. (...) A certain number of CSOs are active in tackling the postwar problems which are not properly addressed by the state, such as offering psychosocial treatment to victims and witnesses in war crime trials, running rehabilitation and reintegration programs for victims of torture, organizing various education and labour market reinsertion programs, managing safe houses for the victims of domestic violence, offering free legal aid services, and running projects for reconciliation and dealing with the past. Three most prominent examples of such NGOs in BiH are Vive žene Tuzla, Medica Zenica and Snaga žene Tuzla." (Impunity Watch, 2012).

Moreover, in $\mathrm{BiH}$ the right to health is not being granted, even though the CEDAW - Committee on the Elimination of Discrimination Against Women, states that the reparation for victims of rape should be granted in terms of Availability, Accessibility, Acceptability and Quality, with "health care protocols and hospital procedures", with "the provision of appropriate health services" and "Gender-sensitive training to enable health care workers to detect and manage the health consequences of gender-based violence" (CEDAW, 2011).

The figures confirm that for every 40,000-50,000 persons, there is just one Centre offering Help for Victims. It can therefor be presumed that in places with a lower density of inhabitants, no assistance is being offered to victims. (Amnesty, 2009).

\section{Conclusions and Final Remarks}

By means of a thorough examination of the reports and extensive bibliography on the topic, by confronting key informants and carrying out interviews, it has been possible to confirm the initial research question and subsequent hypothesis: the reparation mechanisms are not taking place in $\mathrm{BiH}$ and, when they are, they are not sufficiently extensive.

It is evident that at a national and international level, considering both the work of the ICTY and the local authorities, not enough steps have been taken in the direction of effective reparation.

In the Republika Srpska and in the Federation of Bosnia and Herzegovina, the mere Status of Victim of War, with the relative social benefits, is not enough to allow the victims to survive.

The victims who have lost their possessions, their homes and properties, and who qualify as IDPs, are not being granted the right conditions for an adequate and dignified return to their home country. These 'adequate conditions' are not specified in any Statute. Moreover, the raped women, once back in their hometowns, face the possibility of meeting their perpetrators, as the percentage of indicted criminals is still very low. Finally, the necessary physical and psychological rehabilitation is not being provided and, when it is, it is not being carried out in an exhaustive and sufficient manner.

There is a strong need for improvement when addressing the reparation processes both at a national and at an international level. The Tribunals have not shown enough determination in implementing reparation, even though this need has been widely recognised and too much responsibility is being demanded to the NGOs -though they are the most dynamic actors in this process- they are not receiving enough funds for their work.

As Theo Van Boven, Special Rapporteur of the UN Commission on Human Rights on Torture from 2001 to 2004 stated: "Large categories of victims of gross violations of human rights, as a result of the actual contents of national laws or because of the manner in which these laws are applied, fail to receive the reparation which is due to them. Limitations in time, including the application of statutory limitations; restrictions in the definition of scope and nature of the violations; the operation of amnesty laws; the restrictive attitude of courts; the incapability of certain groups of victims to present and to pursue their claims; lack of economic and financial resources: the consequences of all these factors, individually and jointly, is that the principle of equality of rights and due reparation of all victims are not implemented" (UN doc. 
E/CN/4/Sub.2/1993).

The recommendations put forward by the NGOs in their reports massively endorse this statement, as they push for the development of laws at a municipal level, for a prioritization of the cases of rape, for the development and in-depth examination of the Revised Strategy of Bosnia and Herzegovina, for the adoption of Annex VII of the Dayton Peace Agreement, and for a fair and satisfactory allocation of resources to the organizations that are ceaselessly providing the necessary psychological help to survivors of rape.

\section{References}

\section{Documents}

\section{ICC - International Criminal Court}

Assembly of States Parties, Report on Participation on and Reparation to Victims, 25 August 2004, ICC-ASP/3/21, Third Session, The Hague, 6-10 September 2004.

Assembly of States Parties, Report to the Assembly of State Parties on the Activities and Projects of the Board of Directors of the Trust Fund for Victims 2003-2004, Third Session, The Hague, 6-10 September 2004, ICC/ASP/3/14/Re.1, The Hague, 20-22 April 2004.

Report on the International Seminar on Victims' Access to the ICC, PCNICC/1999/WGRPE/INF/2, Second Session of the Preparatory Commission, 26 July-13 August, 6 July 1999.

Report of the Preparatory Committee on the Establishment of an International Criminal Court, Proceedings of the Preparatory Committee during March-April and August 1996, Volume 1, GA 51st Session, Supp. No. 22, A/51/22 (1996), 1 January 1996.

Report of the Preparatory Committee on the Establishment of an International Criminal Court, A/CONF.183/2/Add.1, 14 April 1998.

Resolution ICC-ASP/1/Res.6, Establishment of a Fund for the Benefit of Victims of Crimes within the Jurisdiction of the Court, and of the Families of Such Victims, 9 September 2002.

Resolution ICC-ASP/3/Res.7, Establishment of the Secretariat of the Trust Fund for Victims, 10 September 2004.

United Nations Diplomatic Conference of Plenipotentiaries on the Establishment of an International Criminal Court, Final Act of the United Nations Diplomatic Conference of Plenipotentiaries on the Establishment of an International Criminal Court, Rome, A/CONF.183/10, 17 July 1997.

\section{ICTY - International Criminal Tribunal for the Former Yugoslavia}

ICTY, First Annual Report, (1994).

ICTY, Third Annual Report, (1996).

ICTY, Ninth Annual Report, (2002).

ICTY, Eleventh Annual Report, (2004).

ICTY, Twelfth Annual Report, (2005).

ICTY, Sixteenth Annual Report (2009).

ICTY, Eighteenth Annual Report (2011).

ICTY, Nineteenth Annual Report (2012).

ICTY, Twentieth Annual Report (2013).

Victims Compensation and Participation, Report Prepared by the Rules Committee, 2000.

\section{UN Commission on Human Rights}

Report of the Special Rapporteur on Violence Against Women, Its Causes and Consequences, Ms. Radhika Coomaraswamy, Addendum, Report of the Mission to Rwanda on the Issue of Violence Against Women in Situations of Armed Conflict, 1998.

Resolution 2004/46, Elimination of Violence Against Women, 2004.

Report of the Special Rapporteur on Violence Against Women, Its Causes and Consequences, Yakin Ertürk, Integration of the Human Rights of Women and the Gender Perspective: Violence Against Women - Intersections of Violence Against Women and HIVIAIDS, 2005.

\section{UNIFEM}

Women, War and Peace: The Independent Experts' Assessment on the Impact of Armed Conflict on Women and Women's Role in Peace-building, (2002). 


\section{UN General Assembly}

Resolution 95(I) Affirmation of Principles of International Law Recognized by the Charter of the Nüremberg Tribunal, 1946.

Resolution 488 (V) Formulation of the Nüremberg Principles, 1950.

Resolution 39/46 on the Convention Against Torture and Other Cruel, Inhuman or Degrading Treatment or Punishment, 1984.

\section{UN Security Council}

Resolution 764, on Bosnia and Herzegovina, 1992.

Resolution 771, on the Former Yugoslavia, 1992.

Resolution 780, on the Establishment of a Commission of Experts for the former Yugoslavia, 1992.

Resolution 808, on the Establishment of the ICTY, 1993.

Resolution 820, Bosnia and Herzegovina, 1993.

Resolution 827, on the Establishment of the ICTY, 1993.

\section{WHO - World Health Organization}

Violence Against Women and HIVIAIDS: Critical Intersections, Sexual Violence in Conflict Settings and the Risk of HIV, 2004.

\section{Ngo Reports}

\section{Amnesty International}

Bosnia-Herzegovina: Rape and Sexual Abuse by Armed Forces, 1993.

The International Criminal Court: Preliminary Comments Concerning the Elements of War Crimes Other that Grave Breaches of the Geneva Conventions, 1999.

Bosnia-Herzegovina: Shelving Justice - War Crimes Prosecutions in Paralysis, 2003.

'Whose Justice?' - The Women of Bosnia and Herzegovina Are Still Waiting, 2009.

Public Statement - Bosnia and Herzegovina: Amnesty International calls for justice and reparation for survivors of war crimes of sexual violence, 2010.

Old Crimes, Same Suffering: No justice for Survivors of Wartime Rape in North-East Bosnia and Herzegovina, 2012.

\section{FIDH - Mouvement mondiale des droits de l'homme}

Victims Rights Before the ICC, 2010.

\section{Impunity Watch}

War Victims and Gender-Sensitive Truth, Justice, Reparations and Non-Recurrence in Bosnia and Herzegovina, 2012.

\section{Kvinna till Kvinna}

Equal Power, Lasting Peace: Obstacles for Women's Participation in Peace Processes, 2012.

\section{Stop Rape Now}

Ensuring Justice, Reparations and Rehabilitation for Victims of Conflict Related Sexual Violence, 2012.

\section{TRIAL - Track Impunity Always}

Written Information for the Consideration of Bosnia and Herzegovina's Combined Fourth and Fifth Periodic Reports by the Committee on the Elimination of Discrimination against Women, 2013.

General Allegation on the situation in Bosnia and Herzegovina to the Special Rapporteur on Truth, Justice, Reparations and Guarantees of Non-recurrence, 2014.

\section{Bibliography}

Brownmiller, Susan (1975) Against our will. Men, Women and Rape. New York: Simon and Schuster.

De Brouwer, Anne-marie (2005). Supranational Criminal Prosecution of Sexual Violence. Antwerp - Oxford: Intersentia.

Ginn, Courtney (2013). Ensuring the effective prosecution of sexually violent crimes in the Bosnian War Crimes Chamber: Applying 
lessons from the ICTY. Atlanta: Emory International Law Review; Emory University.

Gow, James; Rachel Kerr \& Zoran Pajić (Eds.) (2013). Prosecuting War Crimes: Lessons and legacies of the International Criminal Tribunal for the Former Yugoslavia. New York: Routledge.

Habermas, Jürgen (1989). The Structural Transformation of the Public Sphere; An Inquiry into a Category of Bourgeois Society. Cambridge: Thomas Burger.

Manjoo, Rashida \& Calleigh, McRaith (2011). Gender-Based Violence and Justice in Conflict and Post-Conflict Areas. New York: Cornell Law School Publications.

Rehn, Elisabeth \& Ellen Johnson Sirleaf (2002). Women, War, Peace: The Independent Experts' Assessment on The Impact of Armed Conflict on Women and Women's Role in Peace-Building. CEDAW Edition.

Swart, Bert; Alexander, Zahar \& Göran, Sluiter (Eds.) (2011). The legacy of the International Criminal Tribunal for the Former Yugoslavia. New York: Oxford University Press.

\section{Webography}

ICTY official website - Hearing, protecting and counselling survivors of sexual violence: http://www.icty.org/sid/10313

ICTY official website - Updated Statute of the International Criminal Tribunal for the Former Yugoslavia: http://www.icty.org/x/file/Legal\%20Library/Statute/statute_sept09_en.pdf

ICTY official website - Rules of Procedure and Evidence: http://www.icty.org/x/file/Legal\%20Library/Rules_procedure_evidence IIT032_Rev43_en.pdf

International Commission on Missing Persons - Guide for Civilian Victims of War, How to enjoy the right to protection as a civilian victim of war in the Republika Srpska: http://www.ic-mp.org/wp-content/uploads/2008/02/guidebook-wictim-of-war-rs.pdf

"Official Gazette" of Bosnia and Herzegovina - Law on Protection of Witnesses Under Threat and Vulnerable Witnesses: http://www.sudbih.gov.ba/files/docs/zakoni/en/BH_LAW_ON_PROTECTION_OF_WITNESSES_-_Consolidated_text.pdf

TRIAL official website: http://www.trial-ch.org/en/about-trial.html

UN Women - United Nations Entity for Gender Equality and the Empowerment of Women: Text of the Convention on the Elimination of all Forms of Discrimination Against Women http://www.un.org/womenwatch/daw/cedaw/cedaw.htm

UN Women - United Nations Entity for Gender Equality and the Empowerment of Women: General recommendations made by the Committee on the Elimination of Discrimination against Women http://www.un.org/womenwatch/daw/cedaw/recommendations /recomm.htm

UN Documents - Beijing Declaration and Platform for Action: The Fourth World Conference on Women, 1995: http://www.un.org/womenwatch/daw/beijing/pdf/BDPfA\%20E.pdf

UN Documents - Resolution 1820: http://www.un.org/en/ga/search/view_doc.asp?symbol=S/RES/1820(2008) 